\title{
Influence of ground cover on earthworm communities in an unmanaged beech forest: linear gradient studies
}

Cyril Campana, Stéphanie Gauvin, Jean-François Ponge*

Museum National d'Histoire Naturelle, Laboratoire d'Écologie Générale, 4 avenue du PetitChâteau, 91800 Brunoy, France

${ }^{*}$ fax +331 60465009, e-mail: jean-francois.ponge@wanadoo.fr

Running title: Influence of ground cover on earthworm species communities

Abstract: Micro-scale changes in earthworm communities and ground cover types were studied along five transect lines in an unmanaged beech forest (Fontainebleau forest, France). Spatial patterns were interpreted to the light of interactions between earthworm species and forest architecture, ground vegetation and quantity as well as quality of litter. The anecic Lumbricus terrestris was associated with patches of the grass Melica uniflora, with poor litter cover, while most epigeic species were favoured by accumulation of litter in the absence of grass vegetation. The endogeic Aporrectodea caliginosa avoided, at least in summer time, 4-year-old gaps opened by wind storms. Under the shade of beeches the evergreen spiny shrub Ruscus aculeatus, and in opened areas the giant herb Phytolacca decandra, seemed repellent to most earthworm species.

Keywords: Lumbricids, Litter, Vegetation, Canopy gaps, Spatial patterns, Correspondence analysis

Résumé: L'influence de la couverture du sol sur les communautés de vers de terre dans une hêtraie naturelle: étude de gradients linéaires. Les changements à petite échelle des communautés de vers de terre et des types de couverture du sol ont été étudiés le long de cinq transects dans une hêtraie naturelle située en forêt de Fontainebleau (France). Les structures spatiales ont été interprétées à la lumière des interactions entre les espèces de vers de terre et 
l'architecture forestière, la végétation au sol ainsi que la quantité et la qualité de la litière. L'espèce anécique Lumbricus terrestris est associée aux tapis de mélique (Melica uniflora), avec une faible couverture de litière, tandis que la plupart des espèces épigées sont favorisées par l'accumulation de litière et l'absence de couverture graminéenne. L'espèce endogée Aporrectodea caliginosa délaisse, tout au moins en période estivale, les clairières ouvertes quatre ans plus tôt par des tempêtes. Ruscus aculeatus, un buisson épineux sempervirent vivant sous le couvert du hêtre, et Phytolacca decandra, une herbacée géante vivant dans les clairières, semblent impropres à la plupart des espèces de vers de terre.

Mots-clés: Lombrics, Litière, Végétation, Trouées, Structures spatiales, Analyse des correspondances 


\section{INTRODUCTION}

The distribution of earthworm species is mainly influenced by water availability [15], acidity [31] and organic matter quantity and quality [27]. In turn, earthworms influence their environment by mucus and urine production [42], by changes in the distribution of organic as well as mineral matter [4], by effects upon ingested soil microflora [23], and by the build-up of soil structure [5]. They influence the fate of vegetation through dispersion/ predation of seed [28], drilling of pores further used by roots [12], and changes in nutrient availability [17].

Earthworm communities are the result of both interactions between species [11] and sensitivity to ecological factors [8]. Despite the aggregative distribution of most earthworm species [6] the use of permanent burrows by anecic species points on some individualistic behaviour [22].

In unmanaged forests the interplay between vegetation and earthworm communities can be studied at different scales. The appearance of gaps in the canopy following single or multiple windthrows or windbreaks is at the origin of the local development of a successional process that ensures the renewal of the forest ecosystem [21]. Earthworms play a part in the regeneration of late-successional trees such as spruce and beech, the forest patchwork being composed of refuge (mature, senescent phase) and depopulation (pole phase) units $[3,35]$. Interactions between earthworms and trees have been suspected to explain at least partly changes in the productivity of beech forests according to site conditions $[34,36]$.

We wonder whether ground vegetation and earthworms interact as well. Presence or absence of ground vegetation and changes in its composition are known to affect the composition of earthworm communities [1] through changes in the distribution and the quality of litter, soil climate, and water availability. In turn, earthworm communities are known to affect ground vegetation through their effects on litter thickness, recycling of nutrients, seed dispersal and physical features of the germination niche [46]. In unmanaged forests, fallen wood [19], and mounds and pits caused by uprooting of trees [9] are additional components of heterogeneity acting at the same scale than patches of ground vegetation. 
Linear gradients crossing units of the forest patchwork allow to sample earthworm communities over a wide array of cover types, and take into account spatial patterns [10, 30, 41]. The question is whether earthworm communities vary at the same scale as the ground cover and, if yes, whether causal relationships can be deduced from co-occurrence data. Whether patches of high and low densities of earthworms are a response to environmental factors or a result from their aggregative behaviour, or both, is still disputed [10, 30, 41]. A combination of multivariate statistics, cross-correlation and autocorrelation methods will be used to discern significant patterns. Possible processes underlying the observed patterns will be discussed.

\section{MATERIALS AND METHODS}

The study site is an unmanaged old-growth forest stand (La Tillaie, 36 ha) located within the Fontainebleau forest (20 $000 \mathrm{ha}$ ), $50 \mathrm{~km}$ south of Paris. Beech (Fagus sylvatica L.) is the dominant tree species, having progressively replaced sessile oak [Quercus petraea (Mattus.) Liebl.] following abandon of pasture during the $16^{\text {th }}$ century then of sylviculture during the $17^{\text {th }}$ century. Geomorphological features are at the origin of a wide variety of soil conditions [35]. Blown sand (fine siliceous Fontainebleau sand) overlays a limestone table, except in a small zone where limestone had been eroded previous to blown sand deposit. The thickness of the blown sand varies from $30 \mathrm{~cm}$ to $230 \mathrm{~cm}$ or more [36]. Access to lime by earthworms and trees determines a variety of humus forms from eumull to dysmoder [35]. Ground vegetation is acidophilic to neutrophilic according to enrichment in calcium of upper soil horizons by beech litter and deep-burrowing earthworms [36]. Rotten logs and branch wood abound on the ground, the fall of woody parts of trees occurring either during senescence of trees or after severe storms [29]. Pits and mounds created by the uprooting of trees are at the origin of a rugged microtopography. A lot of trees fell during storms in 1991, i.e. three years before the present study. The uprooting of trees was at the origin of the establishment then of the expansion of colonies of Virginian poke (Phytolacca decandra L.). Other social heliophytes invaded clearings opened in 1991 or not closed from the last previous storm in 1968, such as bracken (Pteridium aquilinum L.), bramble (Rubus fruticosus L.), wood false-brome [Brachypodium sylvaticum 
(Huds.) Beauv.] and wood small-reed [Calamagrostis epigeios (L.) Roth]. Bushes of butcher's broom (Ruscus aculeatus L.) are quite common under the shade of beech.

Five transects were sampled in July 1994. Their main features are summarized in Table $I$. They differred according to depth of the limestone table, forest architecture, and ground vegetation, but all of them were located on the sites where limestone is accessible to tree roots and deepburrowing animals (i.e. at a depth less than $1 \mathrm{~m}$ ), which harbour the richest earthworm communities [36]. Along each transect line, earthworms were sampled by laying out on the ground stainless steel circles $56 \mathrm{~cm}$ diameter $\left(0.25 \mathrm{~m}^{2}\right.$ surface). Consecutive circles were touching together, thus the sampling step was $56 \mathrm{~cm}$. At the inside of each circle the ground cover was noted, then the litter was discarded when present, after checking for the presence of epigeic earthworms. Earthworms were expelled by sprinkling three times at $10 \mathrm{~min}$ intervals the area within each circle with 5 liters of a diluted formalin solution at increasing concentration $(3 \%$, 4\%, $5 \%$ ). Preliminary sampling by formalin application followed by hand-sorting revealed that in these sandy soils all earthworms present in the top $30 \mathrm{~cm}$ were expelled by formalin.

Collected specimens were preserved into pure formalin, until they were identified at the species level using keys and diagnoses by Sims and Gerard [43] and Bouché [7]. Plant species were identified using Rameau et al. [37]. Data for earthworm species were densities per unit surface. Data for plant species were a semi-quantitative index using fuzzy coding. When only one type of ground cover was present, it was coded 1, when two types were present, each of them was coded 0.5 , etc...

Data were analysed by several methods, separately on each transect. Correspondence analysis [16] was used to analyse a data matrix crossing the different sampling units with earthworm and plant species. Earthworm and ground cover data were active variables, thus took place in the calculation of eigen vectors (factorial axes). Additional data (passive variables) were projected on the factorial axes in order to discern spatial patterns. Each transect line was divided into four linear sections of similar extent, each of them being coded as 1 or 0 for each sampling unit. The projection of these four spatial indices on the plane of the first two factorial axes indicated 
whether the distribution of ground cover types and earthworm species was partly explained by a spatial factor, i.e. they were distributed as patches. All variables were then subjected to reweighting and focusing, i.e. their mean and variance were fixed to 20 and 1 respectively [35]. This allowed factorial coordinates of the different variables to be proportional to their contribution to the factorial axes, whatever the original mean and variance and, thus, whatever the nature of the data (densities, semi-quantitative coding or presence/absence). Active variables were doubled, allowing each variable to be represented on the graphs by a gradient from lower to higher values, thus allowing patterns of increasing richness and abundance to be revealed [36].

The spatial distribution of ground cover types and earthworm species was analysed by autocorrelation $[24,40]$. A high covariance between two series indicates a high degree of spatial relationship between the corresponding sampling units (steps). Given that data were not normally distributed, Spearman rank correlation coefficients were calculated, and were tested by a t-test procedure [44]. The $5 \%$ threshold of significance was used to give an indication of the degree of spatial autocorrelation and to compare successive sampling units along a given transect line.

Spearman rank correlation coefficients were calculated between all variables used in correspondence analysis, in order to verify whether all detectable correlations were taken into account by this multivariate analysis and, if not, to add this information.

\section{RESULTS}

\subsection{Transect $\mathbf{A}$ (single treefall gap within a clump of adult trees)}

Figure 1 shows that both the total abundance and the distribution of earthworm species along transect A were not random. Lumbricus rubellus Hoffmeister, 1843 appears to have a patchy distribution, being abundant from steps (sampling units) 13 to 24, but almost absent from steps 4 to 12 . On the contrary, Dendrobaena octaedra (Savigny, 1826) seems more regularly 
distributed over the whole transect. Such difference in the distribution of these two species was reflected in the evolution of the correlation coefficient between successive sampling units shown by the increase of between-sample distance (figures 2 and 3). The patchy distribution of $L$. rubellus was clearly reflected in the wavy contour of the line (figure 2), passing progressively from positively correlated sampling units at short distance to negatively correlated sampling units when the distance reached 9 to 11 steps (around $5 \mathrm{~m}$ ), then increasing again to positive values when the distance reached 13 to 16 steps (around $8 \mathrm{~m}$ ). On the contrary, the betweensample correlation coefficient was rather erratic with the second most abundant species, $D$. octaedra (figure 3), never reaching any threshold of significance and fluctuating markedly from one step to another. This does not necessarily mean that the former species exhibited a spatial pattern and the latter not, but rather that the sampling distance was probably too large to reveal the spatial pattern of $D$. octaedra.

Ground cover types exhibited a high degree of patchiness (figure 4). Their distribution showed an opposition between a zone where the ground was covered with litter (steps 16 to 23) and a zone covered with the wood melick, Melica uniflora Retz. (steps 4 to 11). The Virginian poke, $P$. decandra, was distributed in a patch on the NE side of the transect, more especially from steps 1 to 3 .

The projection of earthworm and plant species in the plane of axes 1 and 2 of correspondence analysis (19\% and $16 \%$ of the total variance, respectively) displayed a positive relationship between the presence of litter and that of four earthworm species, L. rubellus, Eisenia fetida (Savigny, 1826), D. octaedra and Dendrodrilus rubidus (Savigny, 1826). All these variables were projected on the negative side of Axis 1 (figure 5). Along this axis they were opposed to $P$. decandra and M. uniflora, which were associated with the earthworm species Lumbricus terrestris Linnaeus 1758 and Dendrobaena pygmaea (Savigny, 1826). Axis 2 displayed mostly an opposition between L. rubellus, associated with P. decandra and ivy (Hedera helix L.) on the positive side, and D. octaedra, D. rubidus, and L. castaneus, associated with $M$. uniflora on the negative side. The four sections of transect $A$ were well separated in the plane of axes 1 and 2 . They were scaled along Axis 1, from section 1-6 on the positive side, to section 19-24 on the 
negative side. From the examination of figure 5 it can be concluded that there was a spatial pattern common to ground cover types and earthworm communities, in the form of a gradient from herbaceous vegetation without litter, with $D$. pygmaea and the anecic $L$. terrestris, to littercovered ground with epigeic earthworms. Some detail variations were expressed within the group of epigeic species, associated with changes in the species composition of the herb layer (P. decandra versus M. uniflora).

Spearman rank correlation coefficients helped to verify some of the above mentioned relationships. The negative correlation between, on one side $P$. decandra and $M$. uniflora, on the other side litter cover $\left(r_{s}=-0.49\right.$ and -0.44 , respectively, $\left.P<0.05\right)$, was reflected in Axis 1 , which was positively correlated with the two herb species $\left(r_{s}=0.53, P<0.01\right.$ and $r_{s}=0.40$, $\mathrm{P}<0.05)$ and negatively with litter $\left(r_{s}=-0.85, P<0.01\right)$. This axis was positively correlated with $L$. terrestris $\left(r_{s}=0.57, P<0.05\right)$ and $D$. pygmaea $\left(r_{s}=0.49, P<0.05\right)$, and was negatively correlated with L. rubellus $\left(r_{s}=-0.41, P<0.05\right)$, D. octaedra $\left(r_{s}=-0.60, P<0.01\right)$ and D. rubidus $\left(r_{s}=-0.54\right.$, $\mathrm{P}<0.01)$. L. rubellus was positively correlated with litter $\left(r_{s}=0.57, P<0.01\right)$, and negatively correlated with $M$. uniflora $\left(r_{s}=-0.64, P<0.01\right)$. Axis 2 was negatively correlated with $M$. uniflora $\left(r_{s}=-0.67, P<0.01\right), D$. octaedra $\left(r_{s}=-0.44, P<0.05\right)$, L. castaneus $\left(r_{s}=-0.48, P<0.05\right)$ and $D$. rubidus $\left(r_{s}=-0.41, P<0.05\right)$ and was positively correlated with $L$. rubellus $\left(r_{s}=0.73, P<0.01\right)$. A patchy distribution was perceptible in the distribution of $P$. decandra $\left(r_{s}=0.49\right), M$. uniflora $\left(r_{s}=0.48\right)$, litter $\left(r_{s}=0.65\right)$, L. rubellus $\left(r_{s}=0.54\right)$ and L. castaneus $\left(r_{s}=0.45\right)$.

Given that correspondence analysis summarized results from analytical studies (correlation and autocorrelation coefficients), only results from correspondence analyses will be presented in the following, and reference to analytical studies will be made only when necessary.

\subsection{Transect B (Succession of pole stage, multiple treefall gap and senescent stage)}

Transect $\mathrm{B}$, which was more complex than transect $\mathrm{A}$, crossed a pole stage, followed by a multiple treefall gap then by a senescent stage of the beech ecosystem (table I). Axis 1 of correspondence analysis ( $15 \%$ of the total variance) revealed a sequence from pole stage to 
senescent stage then to the multiple treefall gap, which followed a gradient of aperture of the canopy rather than a spatial scaling from NW to SE (figure 6). The multiple treefall gap (positive side of Axis 1) was characterized by the disappearance of litter and the development of bramble (Rubus fruticosus L.) and, to a lesser extent, by the presence of rotten wood, H. helix, Lonicera periclymenum L., Carex spp., and Euphorbia amygdaloides L. Some earthworm species, both endogeic [Aporrectodea rosea (Savigny, 1826)] and epigeic (E. fetida, D. rubidus), were associated with this part of the transect (steps 20 to 37). The arbitrary section 23-33 (near superposable to the gap) was accordingly projected far from the origin, on the positive side of Axis 1 . On the opposite side of Axis 1 , the pole stage was characterized by litter, the near absence of ground vegetation and the presence of mole hills. Earthworm populations were mainly composed of the endogeic Aporrectodea caliginosa (Savigny, 1826), which reached 65 ind. $\mathrm{m}^{-2}$ at step 12 , and was the only earthorm species to show a patchy distribution. The senescent stage exhibited intermediary features, if we except the presence of fallen wood which was strongly associated with this stage. This particular feature of the senescent stage was reflected in Axis 3 (result not shown), which isolated fallen wood from the other variables describing cover types or earthworm populations. Axis 2 (13\% of the total variance) revealed some heterogeneity in earthworm communities within the multiple treefall gap, opposing $D$. rubidus and L. terrestris, without any clear relationship with other earthworm species and with ground cover types, if we discard some scarcely represented items such as Carex spp., $A$. rosea, E. amygdaloides, and rotten wood. Examination of individual data and correlation coefficients revealed that $L$. terrestris was present in a sampling unit only when $D$. rubidus was absent, despite the absence of pachy distribution. Some weak positive relationship between $L$. terrestris and $H$. helix, which had a patchy distribution, was nevertheless expressed by Axis 2 , too.

\subsection{Transect $C$ (Mixing of different age classes of beech)}

The limestone table was fairly close to the ground surface $(45 \mathrm{~cm})$ and the earthworm community was strongly dominated by L. terrestris (up to 40 ind. $\mathrm{m}^{-2}$ ). Axis 1 of correspondence analysis $(21 \%$ of the total variance) displayed a clear opposition between places covered with 
litter and places covered with bushes of the evergreen $R$. aculeatus (figure 7). The abundance of most earthworm species (except a few individuals of $D$. rubidus) decreased from litter- to Ruscus-covered places. Axis 2 (15\% of the total variance) exhibited only a minor phenomenon, which was the presence of an unique individual of $L$. rubellus in the vicinity of a trunk base at step 1.

\subsection{Transect $D$ (Mixed pole stage of beech and ash)}

Axis 1 of correspondence analysis ( $26 \%$ of the total variance) revealed an opposition between zones occupied by M. uniflora and L. terrestris (positive side) and zones occupied by litter and an assemblage of the other earthworm species, among them the most abundant were the endogeic $A$. caliginosa and the epigeic D. pygmaea, L. rubellus, and D. rubidus (figure 8). These zones were wide, as this could be ascertained by the wide spacing along Axis 1 of the four artificial sections of the transect, mainly between steps $8-14$ and steps $22-27$. Axis 2 (22\% of the total variance) showed that most earthworm species were absent from places occupied by $R$. aculeatus, except a small population of $D$. pygmaea and $L$. rubellus.

\subsection{Transect $E$ (Double treefall gap within a mixing of different age classes of beech)}

Despite the complexity of this transect, correspondence analysis (figure 9) revealed important patterns. Axis 1 (12\% of the total variance) opposed section $11-20$ to the other three sections. On the positive side of this axis cover types indicating a sunny exposure, such as $P$. aquilinum, mound (from an uprooted tree), Polytrichum formosum Hedw. and Ilex aquifolium L., were found. The epigeic earthworms $D$. rubidus and E. fetida were present at those sunny places. On the negative side of Axis 1 typical cover types were litter and M. uniflora, with the earthworms $D$. octaedra and L. terrestris (L. castaneus can be neglected, being occasional). Axis 2 ( $10 \%$ of the total variance) revealed an opposition between $M$. uniflora on the positive side, and litter together with $R$. fruticosus on the negative side. L. terrestris was associated with melick on the positive side of this axis (together with the neglectable $L$. eiseni), opposed to $L$. rubellus associated with litter and bramble on the negative side. Litter exhibited a high spatial 
autocorrelation (patchy distribution), while bramble did not, thus indicating a sparse population of $R$. fruticosus.

\section{DISCUSSION}

It is probable that at the time of the present study (July) some species such as Aporrectodea longa retreated deep in their burrows and were in a phase of quiescence [43] but all other species previously found on the site $[35,36]$ were retrieved, indicating that aestivation did not affect the studied site to a great extent.

Most results obtained along transect A were attributed to spatial patterns, since most significant positive or negative correlations with Axis 1 of correspondence analysis were found with patchy distributed earthworm species and ground cover types. Nevertheless some relationships, not based on patchy distributions, were revealed by correspondence analysis, such as for instance the positive correlation between $D$. octaedra and $D$. rubidus (figure 5), despite neglectable autocorrelation coefficients $\left(r_{s}=-0.07\right.$ and -0.03 , respectively). The observed spatial patterns can be explained by variations in the exposure of the ground surface to sunlight, since this transect crossed a single-tree windstorm gap within a clump of adult trees (table I). The northeastern side of the transect received more light than the opposite side, thus we can hypothesize a succession from NE to SW made of social heliophytes such as Phytolacca decandra [13], followed by sylvatic grasses such as Melica uniflora [25], then by litter only. The presence of litter on the south-western side of the transect only explains the spatial pattern of litter-dwelling earthworm species such as $L$. rubellus, $E$. fetida, $D$. octaedra and $D$. rubidus. The absence of litter under $P$. decandra and $M$. uniflora can be explained by the burial activity of Lumbricus terrestris [38] rather than by some heterogeneity in the fall of litter, given the small size (13 $\mathrm{m})$ of this single-tree gap, compared to $40 \mathrm{~m}$ for the height of adult beech at this location [29]. The association of $L$. terrestris with herbaceous vegetation is explained by its preference for a more diversified food than pure beech litter, as was demonstrated by Judas [18]. Some spatial segregation between $P$. decandra and $M$. uniflora, which had been observed when mapping vegetation on the same site (unpublished data) explains Axis 2 of correspondence analysis 
(figure 5) which opposed these two species, associated with a variation in epigeic earthworm communities ( $L$. rubellus under P. decandra; L. castaneus, D. rubidus, and D. octaedra under M. uniflora). Possible antagonisms between $L$. rubellus, $D$. rubidus and $D$. octaedra could be excluded, since these species cohabited in litter-dominated samples, but such a negative interaction cannot be excluded between $L$. rubellus and L. castaneus, which were spatially segregated. True mechanisms linking earthworm species to either one or the other plant species are totally unknown, but the subterranean system of $P$. decandra (big tuberculate roots) is particularly rich in saponins known to kill snails [26], a locally selective effect of plants which has been observed in earthworm communities under herbaceous vegetation [1].

Transect B exhibited a sequence of wavelike regeneration of the beech forest [20]. Limestone was present at $63 \mathrm{~cm}$ depth, thus in a shallower position compared to transect $\mathrm{A}(80 \mathrm{~cm})$, which may explain the presence of endogeic species such as $A$. caliginosa, O. cyaneum and A. rosea, absent from the former, more acidic transect [36]. Here, most changes in the distribution of earthworm species are explained by microclimate changes due to the presence or absence of litter and shade versus light. The near disappearance in the gap of active individuals of the dominant $A$. caliginosa is explained by drier conditions prevailing in summer in the first top centimeters of the soil [14], reinforced by the presence of a luxuriant bramble vegetation which depletes the soil in water. The segregation observed within the gap between $L$. terrestris and $D$. rubidus (both species without any patchy distribution) does not correspond to changes in vegetation cover or microclimate gradients, but rather to some unexplained antagonism between them.

The most clear trend observed along transect $C$ was the spotty distribution of $R$. aculeatus, to which can be attributed the heterogeneity of both litter and earthworm populations. This sunintolerant evergreen spiny shrub lives under the canopy of beech but prevents foliage beech litter from reaching the ground (personal observations). This particular behaviour causes probably a shortage in nutrients underneath, mainly in carbon and nitrogen, notwithstanding some possible biochemical repellence of the plant against earthworms. 
Transect $D$ exhibited features quite similar to transect $A$, except that it was not located within a gap. A zone covered with M. uniflora, occupied by L. terrestris, was opposed to a zone without grasses but covered with litter, occupied by an earthworm community dominated by several epigeic species and the endogeic $A$. caliginosa. The same interpretation as above can be given of these results, namely an attraction of $L$. terrestris to grass vegetation, leaving patches of litter-covered ground available to epigeic species. The scarcity of $A$. caliginosa in the melick zone could be explained by drier conditions in the first top centimeters under grass vegetation [14], or to negative interactions between earthworm species [11]. Nevertheless a negative interaction between $L$. terrestris and $A$. caliginosa could be excluded, since these two species were often collected together along transect C (figure 7) and were often collected together in other studies [2, 32, 45].

Changes in species composition of earthworm communities along transect $E$ were mostly explained by the alternation of sunny and shady places, and by patches of grass vegetation under the canopy of beeches. The association between $L$. terrestris and M. uniflora led to a partitioning of the forest floor between zones with few litter and a grass cover occupied by anecic worms and zones with litter and without grasses occupied by epigeic species, mainly $L$. rubellus.

Although each transect studied exhibited its own characteristics, common trends were perceived, such as the avoidance of drier sites by $A$. caliginosa in summer time and the partitioning of the forest floor under the canopy of beech according to the development of grass vegetation. Other trends concerned possible interactions between some earthworm species and a possible negative effect of some plants such as Ruscus aculeatus and $P$. decandra against earthworms. According to the size at which these processes were acting, they were or not revealed by the patchy distribution of plant and earthworm species. Correspondence analysis helped to reveal the corresponding patterns and allowed to distinguish between spatially and not spatially distributed patterns. Since we know that the spatial distribution of plants as well as animals is the result of both internal (growth, reproduction) and external (selection, choice) interactions [33,41], it ensues that the partialling out of the spatial component of ecological 
variation using Mantel tests [24] can be considered as a complete waste of time. It can be claimed on a sound basis that spatial and time patterns are the result of ecological processes acting both in space and time [48] and cannot be dealed with as a separate environmental factor. If mapping is needed, data can be adjusted to a spatial model used to interpolate between samples [10]. If ecological relationships are to be searched, a pure spatial treatment of data by methods such as geostatistics [39] or related methods [47] may mask most important environmental effects. Thus, the use of multivariate methods, which take into account a great number of active and passive variables, may reveal spatial patterns at the community level, which could better explain the behaviour of individual species.

\section{REFERENCES}

[1] Babel U., Ehrmann O., Krebs M., Relationships between earthworms and some plant species in a meadow, Soil Biol. Biochem. 24 (1992) 1477-1481.

[2] Bernier N., Earthworm feeding activity and development of the humus profile, Biol. Fertil. Soils 26 (1998) 215-223.

[3] Bernier N., Ponge J.F., Humus form dynamics during the sylvogenetic cycle in a mountain spruce forest, Soil Biol. Biochem. 26 (1994) 183-220.

[4] Binet F., Curmi P., Structural effects of Lumbricus terrestris (Oligochaeta: Lumbricidae) on the soil-organic matter system: micromorphological observations and autoradiographs, Soil Biol. Biochem. 24 (1992) 1519-1523.

[5] Blanchart E., Lavelle P., Spain A.V., Effects of biomass and size of Millsonia anomala (Oligochaeta: Acanthodrilidae) on particle aggregation in a tropical soil in the presence of Panicum maximum (Gramineae), Biol. Fertil. Soils 10 (1990) 113-120.

[6] Boag B., Legg R.K., Neilson R., Palmer L.F., Hackett C.A., The use of Taylor's Power Law to describe the aggregated distribution of earthworms in permanent pasture and arable soil in Scotland. Pedobiologia 38 (1994) 303-306.

[7] Bouché M.B., Lombriciens de France. Écologie et systématique, INRA, Paris, 1972.

[8] Briones M.J.I., Mascato R., Mato S., Autoecological study of some earthworm species (Oligochaeta) by means of ecological profiles, Pedobiologia 39 (1995) 97-106. 
[9] Brown J.L., Étude de la perturbation des horizons du sol par un arbre qui se renverse et de son impact sur la pédogénèse, Can. J. Soil Sci. 57 (1977) 173-186.

[10] Cannavacciulo M., Bellido A., Cluzeau D., Gascuel C., Trehen P., A geostatistical approach to the study of earthworm distribution in grassland, Appl. Soil Ecol. 9 (1998) 345-349.

[11] Capowiecz Y., Differences in burrowing behaviour and spatial interaction between the two earthworm species Aporrectodea nocturna and Allolobophora chlorotica, Biol. Fertil. Soils 30 (2000) 341-346.

[12] Edwards C.A., Lofty J.R., The influence of arthropods and earthworms upon root growth of direct drilled cereals. J. Appl. Ecol. 15 (1978) 789-795.

[13] Faille A., Influence sur la végétation herbacée de l'ouverture de trouées dans les réserves biologiques de la forêt de Fontainebleau, Bull. Écol. 11 (1980) 1-10.

[14] Fardjah M., Lemée G., Pontailler J.Y., Dynamique comparée de l'eau sous hêtraie et dans des coupes nues ou à Calamagrostis epigeios en forêt de Fontainebleau, Bull. Écol. 11 (1980) 11-31.

[15] Gerard B.M., Factors affecting earthworms in pastures, J. Anim. Ecol. 36 (1967) 235252.

[16] Greenacre M.J., Theory and applications of correspondence analysis, Academic Press, London, 1984.

[17] Haimi J., Einbork M., Effects of endogeic earthworms on soil processes and plant growth, Biol. Fertil. Soils 13 (1992) 6-10

[18] Judas M., Gut content analysis of earthworms (Lumbricidae) in a beechwood, Soil Biol. Biochem. 24 (1992) 1413-1417.

[19] Klinka K., Lavkulich L.M., Wang Q., Feller M.C., Influence of decaying wood on chemical properties of forest floors and surface mineral soils: a pilot study, Ann. Sci. For. 52 (1995) 523-533.

[20] Koop H., Forest dynamics. SILVI-STAR: a comprehensive monitoring system, SpringerVerlag, Berlin, 1989. 
[21] Koop H., Hilgen P., Forest dynamics and regeneration mosaic shifts in unexploited beech (Fagus sylvatica) stands at Fontainebleau (France), For. Ecol. Manag. 20 (1987) 135-150.

[22] Kretzschmar A., Soil partitioning effect of an earthworm burrow system, Biol. Fertil. Soils $3(1987) 121-124$

[23] Krištufek V., Ravasz K., Pižl V., Changes in densities of bacteria and microfungi during gut transit in Lumbricus rubellus and Aporrectodea caliginosa (Oligochaeta: Lumbricidae), Soil Biol. Biochem. 24 (1992) 1499-1500.

[24] Legendre P., Fortin M.J., Spatial pattern and ecological analysis, Vegetatio 80 (1989) 107-138.

[25] Lemée G., Recherches sur les écosystèmes des réserves biologiques de la forêt de Fontainebleau. III. Influence du peuplement graminéen sur les caractères et l'activité biologique du mull acide, Rev. Écol. Biol. Sol 12 (1975) 157-167.

[26] Mabberley D.J., The plant book. A portable dictionary of the vascular plants. $2^{\text {nd }}$ edition, Cambridge University Press, Cambridge, 1997.

[27] McLean M.A., Kolodka D.U., Parkinson D., Survival and growth of Dendrobaena octaedra (Savigny) in pine forest floor materials, Pedobiologia 40 (1996) 281-288.

[28] McRill M., Sagar G.R., Earthworms and seeds, Nature 243 (1973) 482-482.

[29] Peltier A., Touzet M.C., Armengaud C., Ponge J.F., Establishment of Fagus sylvatica and Fraxinus excelsior in an old-growth beech forest, J. Veg. Sci. 8 (1997) 13-20.

[30] Phillipson J., Abel R., Steel J., Woodell S.R.J., Earthworms and the factors governing their distribution in an English beechwood, Pedobiologia 16 (1976) 258-285.

[31] Piearce T.G., Acid intolerant and ubiquitous Lumbricidae in selected habitats in North Wales, J. Anim. Ecol. 41 (1972) 397-410.

[32] Pitkänen J., Nuutinen V., Distribution and abundance of burrows formed by Lumbricus terrestris L. and Aporrectodea caliginosa Sav. in the soil profile, Soil Biol. Biochem. 29 (1997) 463-467.

[33] Ponge J.F., André J., Zackrisson O., Bernier N., Nilsson M.C., Gallet C. The forest regeneration puzzle: biological mechanisms in humus layer and forest vegetation dynamics, BioScience 48 (1998) 523-530. 
[34] Ponge J.F., Arpin P., Sondag F., Delecour F., Soil fauna and site assessment in beech stands of the Belgian Ardennes, Can. J. For. Res. 27 (1997) 2053-2064.

[35] Ponge J.F., Delhaye L., The heterogeneity of humus profiles and earthworm communities in a virgin beech forest, Biol. Fertil. Soils 20 (1995) 24-32.

[36] Ponge J.F., Patzel N., Delhaye L., Devigne E., Levieux C., Beros P., Wittebrodt R., Interactions between earthworms, litter and trees in an old-growth beech forest, Biol. Fertil. Soils 29 (1999) 360-370.

[37] Rameau J.C., Mansion D., Dumé G., Flore forestière française, guide écologique illustré. I. Plaines et collines, IDF, Paris, 1989.

[38] Raw F, Studies of earthworm populations in orchards. I. Leaf burial in apple orchards, Ann Appl. Biol. 50 (1962) 389-404.

[39] Robertson G.P., Geostatistics in ecology: interpolating with known variance, Ecology 68 (1987) $744-748$.

[40] Rossi J.P., Statistical tool for soil biology. XI. Autocorrelogram and Mantel test, Eur. J. Soil Biol. 32 (1996) 195-203.

[41] Rossi J.P., Lavelle P., Albrecht A., Relationships between spatial pattern of the endogeic earthworm Polypheretima elongata and soil heterogeneity, Soil Biol. Biochem. 29 (1997) 485-488.

[42] Schrader S., Influence of earthworms on the $\mathrm{pH}$ conditions of their environment by cutaneous mucus secretion, Zool. Anz. 233 (1994) 211-219.

[43] Sims R.W., Gerard B.M., Earthworms. Keys and notes for the identification and study of the species, Brill and Backhuys, London, 1995.

[44] Sokal R.R., Rohlf F.J., Biometry. The principles and practice of statistics in biological research, Freeman, New York, 1995.

[45] Sveistrup T.E., Haraldsen T.K., Engelstad F., Earthworm channels in cultivated clayey and loamy Norwegian soils, Soil Tillage Res. 43 (1997) 251-262.

[46] Thompson L., Thomas C.D., Radley J.M.A., Williamson S., Lawton J.H., The effect of earthworms and snails in a simple plant community, Oecologia 95 (1993) 171-178. 
[47] Usher M.B., Booth R.G., Arthropod communities in a maritime antarctic moss-turf habitat: multiple scales of pattern in the mites and Collembola, J. Anim. Ecol. 55 (1986) 155-170.

[48] Watt A.S. Pattern and process in the plant community, J. Ecol. 35 (1947) 1-22. 


\section{LEGENDS OF FIGURES}

Fig. 1. Distribution of earthworm species along transect $A$. Distance between successive steps $56 \mathrm{~cm}$

Fig. 2. Autocorrelation coefficients between successive densities of Lumbricus rubellus along transect A. Distance between successive steps $56 \mathrm{~cm}$. Confidence limits of Spearman rank correlation coefficients indicated by dashed lines (only indicative, see text)

Fig. 3. Autocorrelation coefficients between successive densities of Dendrobaena octaedra along transect A. Distance between successive steps $56 \mathrm{~cm}$. Confidence limits of Spearman rank correlation coefficients indicated by dashed lines (only indicative, see text)

Fig. 4. Distribution of ground cover types along transect A. Distance between successive steps $56 \mathrm{~cm}$

Fig. 5. Correspondence analysis of earthworm and cover type data along transect A. Projection of active (earthworm and plant species) and passive (spatial sections) variables in the plane of the first two factorial axes

Fig. 6. Correspondence analysis of earthworm and cover type data along transect B. Projection of active (earthworm and plant species) and passive (spatial sections, forest architecture stages) variables in the plane of the first two factorial axes

Fig. 7. Correspondence analysis of earthworm and cover type data along transect C. Projection of active (earthworm and plant species) and passive (spatial sections) variables in the plane of the first two factorial axes 
Fig. 8. Correspondence analysis of earthworm and cover type data along transect D. Projection of active (earthworm and plant species) and passive (spatial sections) variables in the plane of the first two factorial axes

Fig. 9. Correspondence analysis of earthworm and cover type data along transect E. Projection of active (earthworm and plant species) and passive (spatial sections) variables in the plane of the first two factorial axes 
Table 1. Main features of the five studied transects

\begin{tabular}{|c|c|c|c|c|c|}
\hline & Transect A & Transect B & Transect C & Transect D & Transect E \\
\hline Orientation & NE-SW & NW-SE & SW-NE & W-E & SW-NE \\
\hline Length & $13.4 \mathrm{~m}$ & $25.2 \mathrm{~m}$ & $18.5 \mathrm{~m}$ & $15.1 \mathrm{~m}$ & $21.8 \mathrm{~m}$ \\
\hline Global description & $\begin{array}{l}\text { Single treefall } \\
\text { gap within a } \\
\text { clump of adult } \\
\text { trees }\end{array}$ & $\begin{array}{l}\text { Succession of } \\
\text { pole stage, } \\
\text { multiple treefall } \\
\text { gap and } \\
\text { senescent stage }\end{array}$ & $\begin{array}{l}\text { Mixing of } \\
\text { different age } \\
\text { classes of beech }\end{array}$ & $\begin{array}{l}\text { Mixed pole stage } \\
\text { of beech and ash }\end{array}$ & $\begin{array}{l}\text { Double treefall } \\
\text { gap within a } \\
\text { mixing of } \\
\text { different age } \\
\text { classes of beech }\end{array}$ \\
\hline $\begin{array}{l}\text { Mean depth of } \\
\text { limestone }\end{array}$ & $80 \mathrm{~cm}$ & $63 \mathrm{~cm}$ & $45 \mathrm{~cm}$ & $89 \mathrm{~cm}$ & $105 \mathrm{~cm}$ \\
\hline $\begin{array}{l}\text { Dominant ground } \\
\text { cover types }\end{array}$ & $\begin{array}{l}\text { Litter, Melica } \\
\text { uniflora, } \\
\text { Phytolacca } \\
\text { decandra }\end{array}$ & $\begin{array}{l}\text { Litter, Fallen } \\
\text { wood, Ruscus } \\
\text { aculeatus, } \\
\text { Hedera helix }\end{array}$ & $\begin{array}{l}\text { Litter, Ruscus } \\
\text { aculeatus }\end{array}$ & $\begin{array}{l}\text { Litter, Melica } \\
\text { uniflora, Ruscus } \\
\text { aculeatus, } \\
\text { Festuca } \\
\text { heterophylla }\end{array}$ & $\begin{array}{l}\text { Litter, Pteridium } \\
\text { aquilinum, } \\
\text { Brachypodium } \\
\text { sylvaticum, } \\
\text { Mounds }\end{array}$ \\
\hline $\begin{array}{l}\text { Dominant } \\
\text { earthworm species }\end{array}$ & $\begin{array}{l}\text { Lumbricus } \\
\text { rubellus, } \\
\text { Dendrobaena } \\
\text { octaedra }\end{array}$ & $\begin{array}{l}\text { Lumbricus } \\
\text { terrestris, } \\
\text { Aporrectodea } \\
\text { caliginosa }\end{array}$ & $\begin{array}{l}\text { Lumbricus } \\
\text { terrestris, } \\
\text { Aporrectodea } \\
\text { caliginosa }\end{array}$ & $\begin{array}{l}\text { Lumbricus } \\
\text { terrestris, } \\
\text { Dendrobaena } \\
\text { pygmaea }\end{array}$ & $\begin{array}{l}\text { Lumbricus } \\
\text { rubellus, } \\
\text { Lumbricus } \\
\text { terrestris, } \\
\text { Dendrodrilus } \\
\text { rubidus, } \\
\text { Dendrobaena } \\
\text { octaedra }\end{array}$ \\
\hline
\end{tabular}




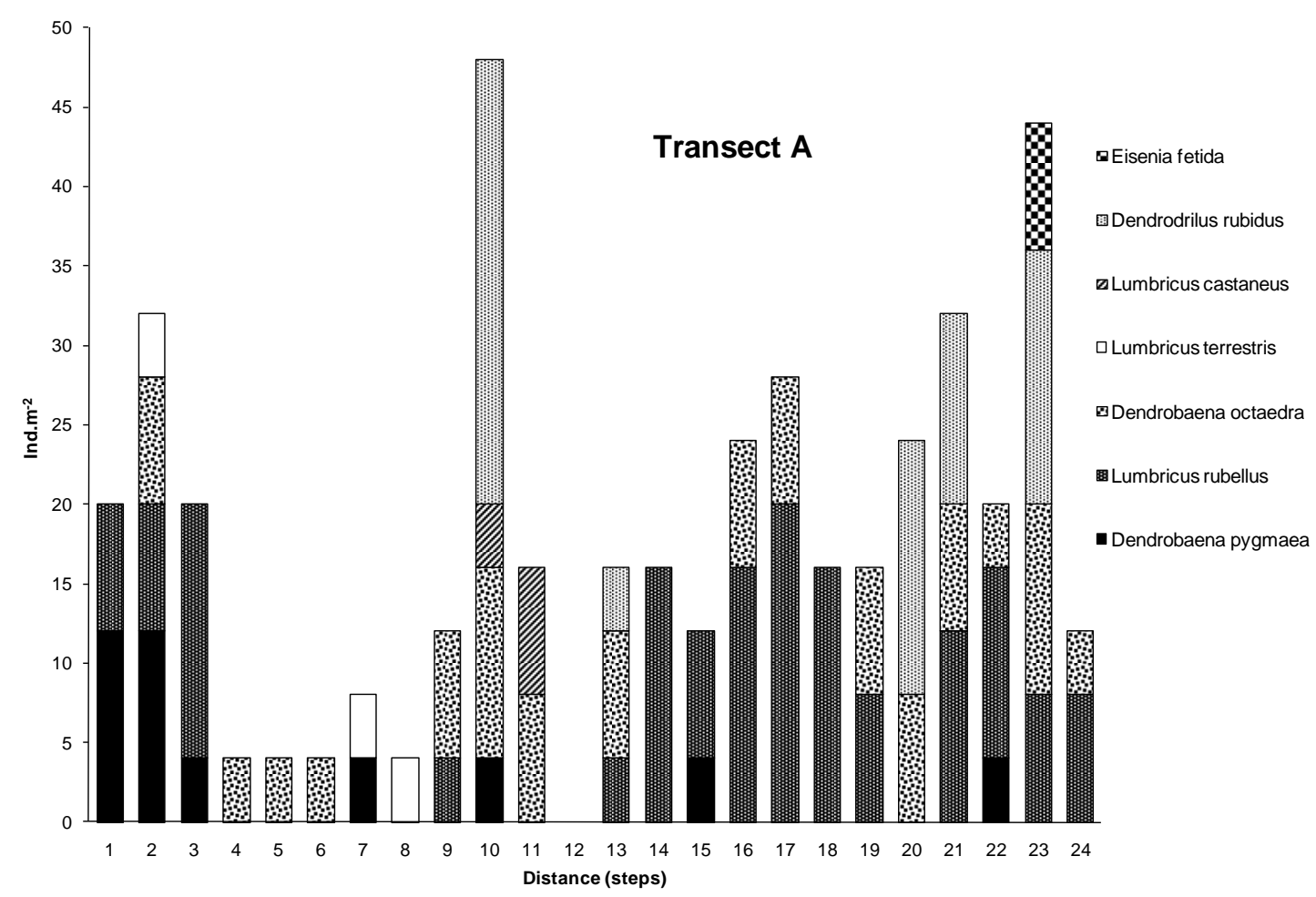

Fig. 1 


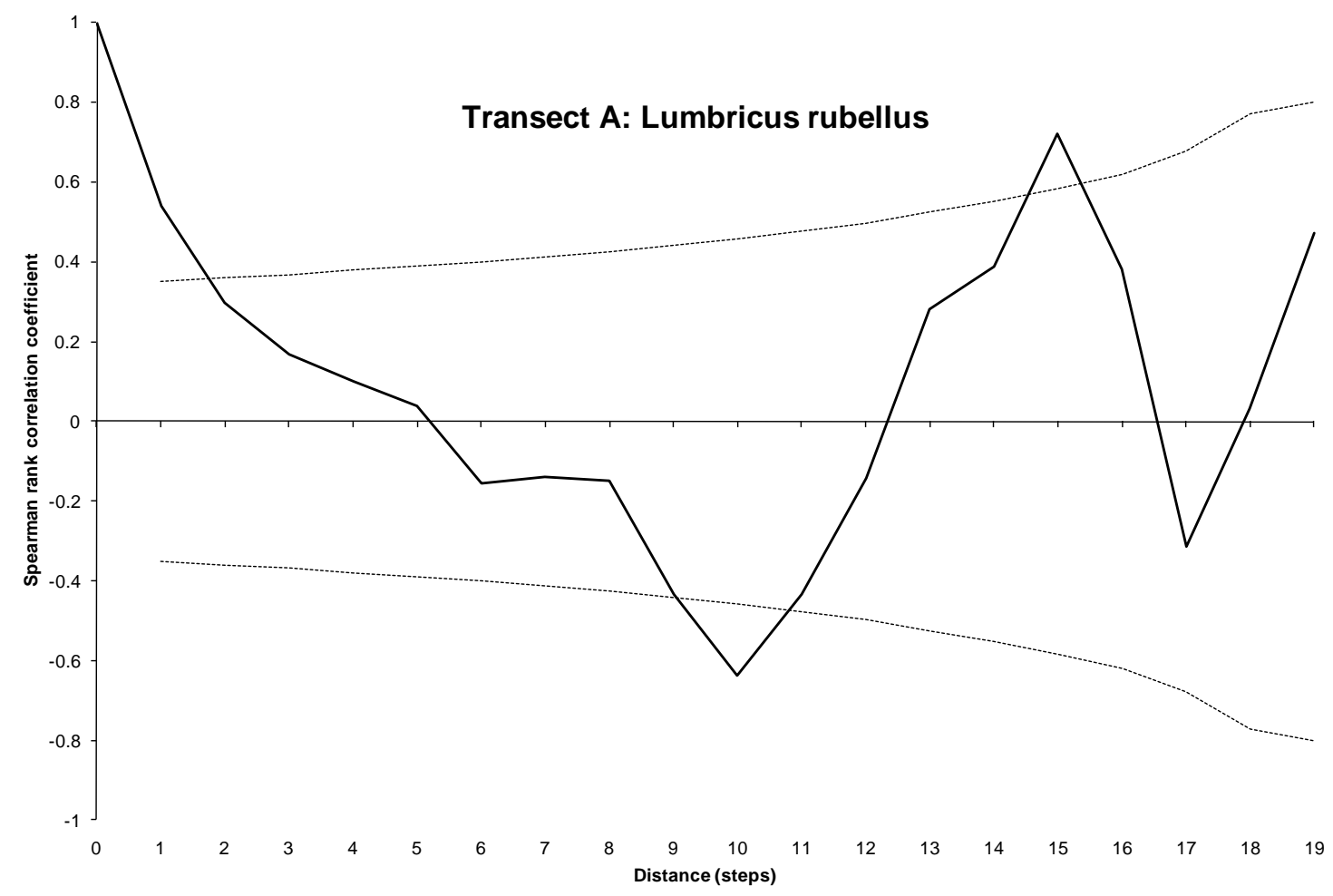

Fig. 2 


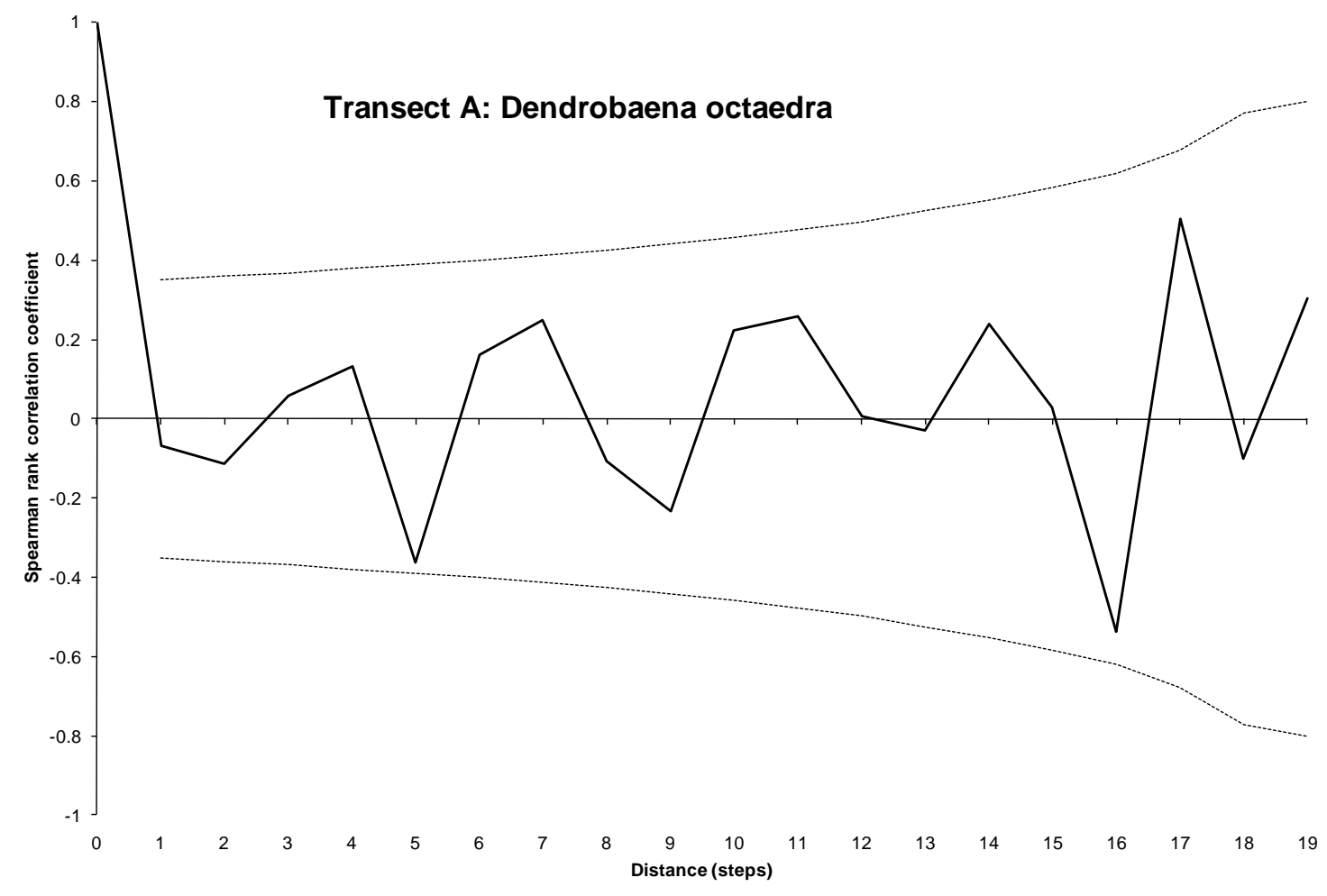

Fig. 3 
Transect A

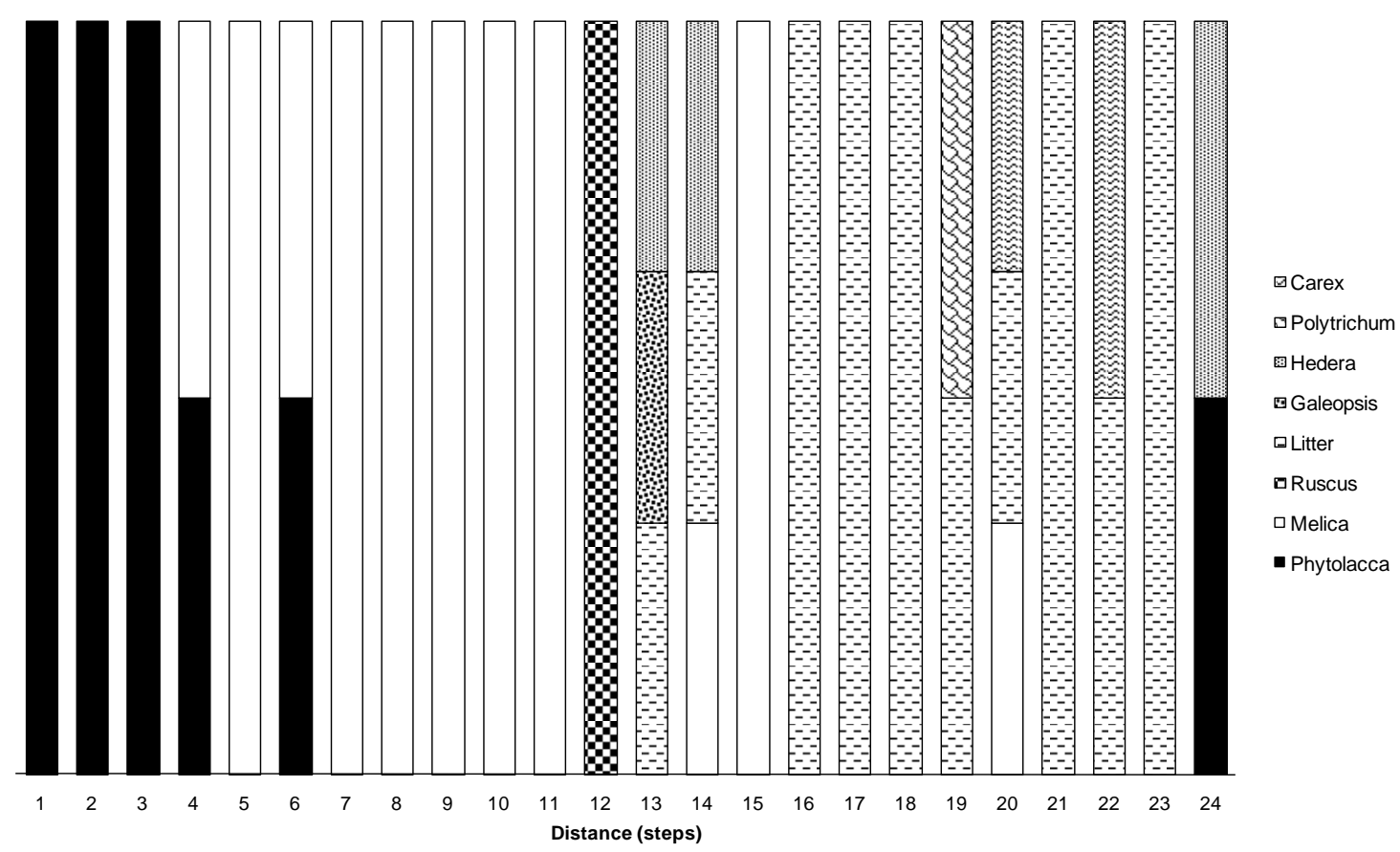

Fig. 4 


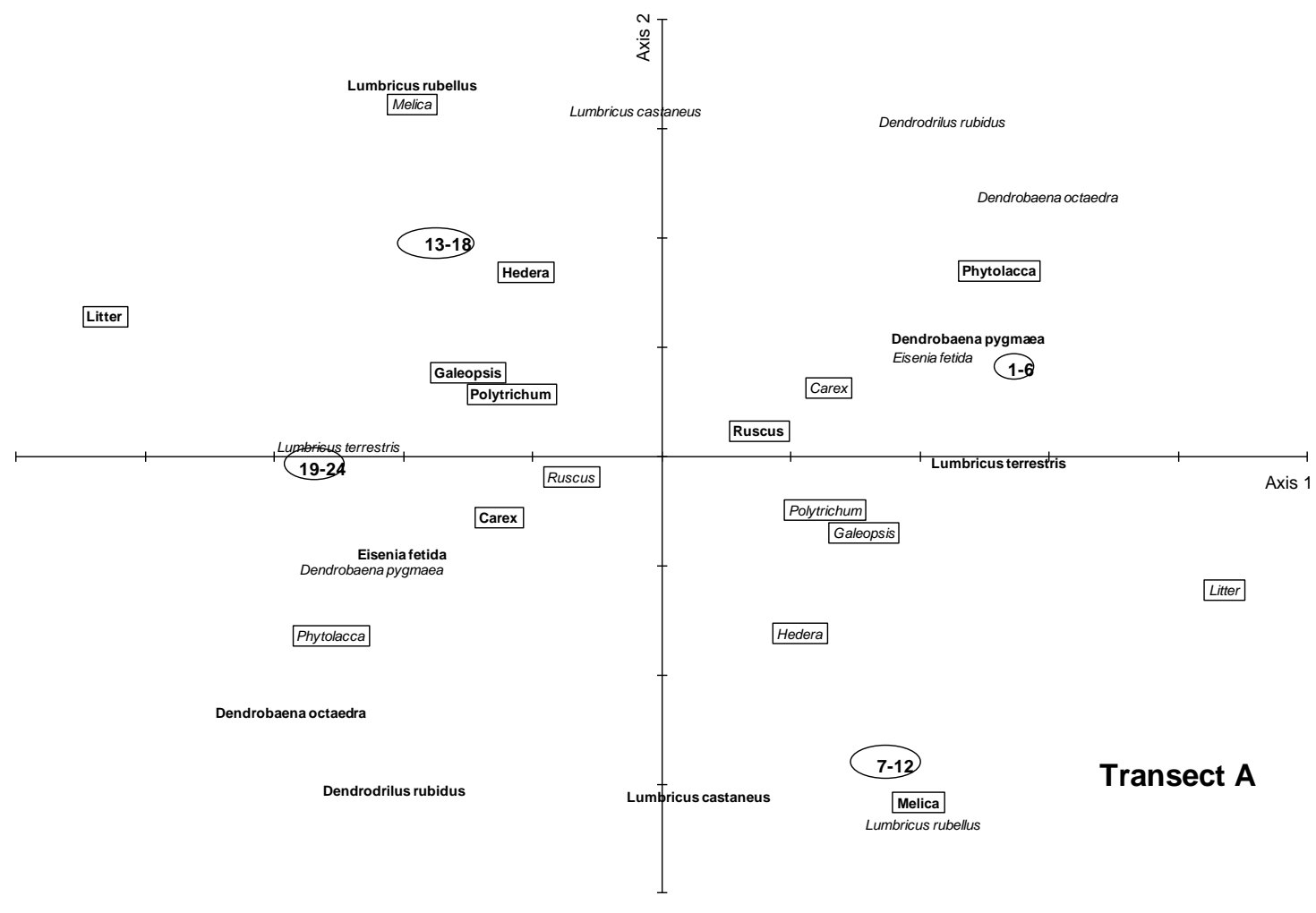

Fig. 5 


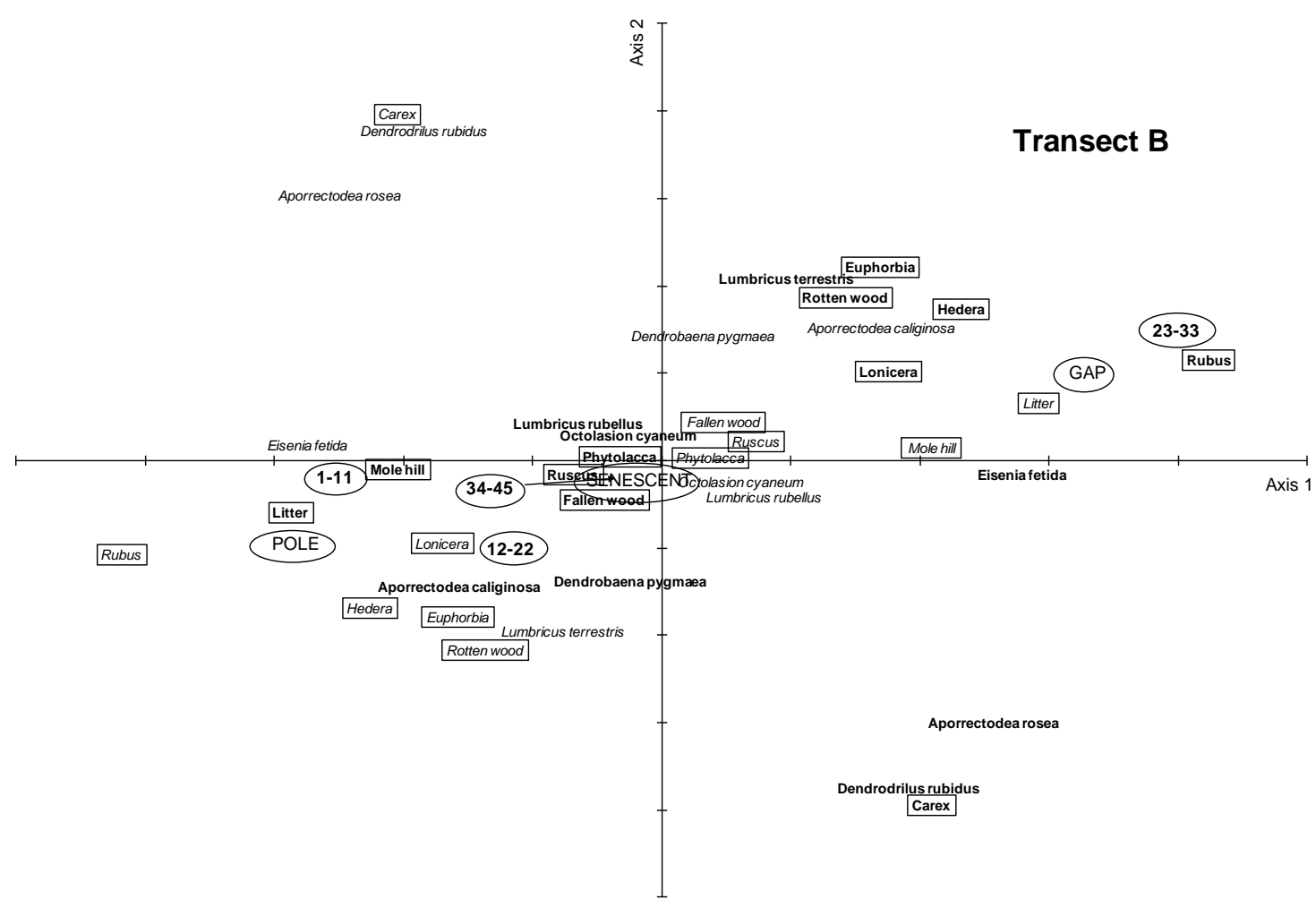

Fig. 6 


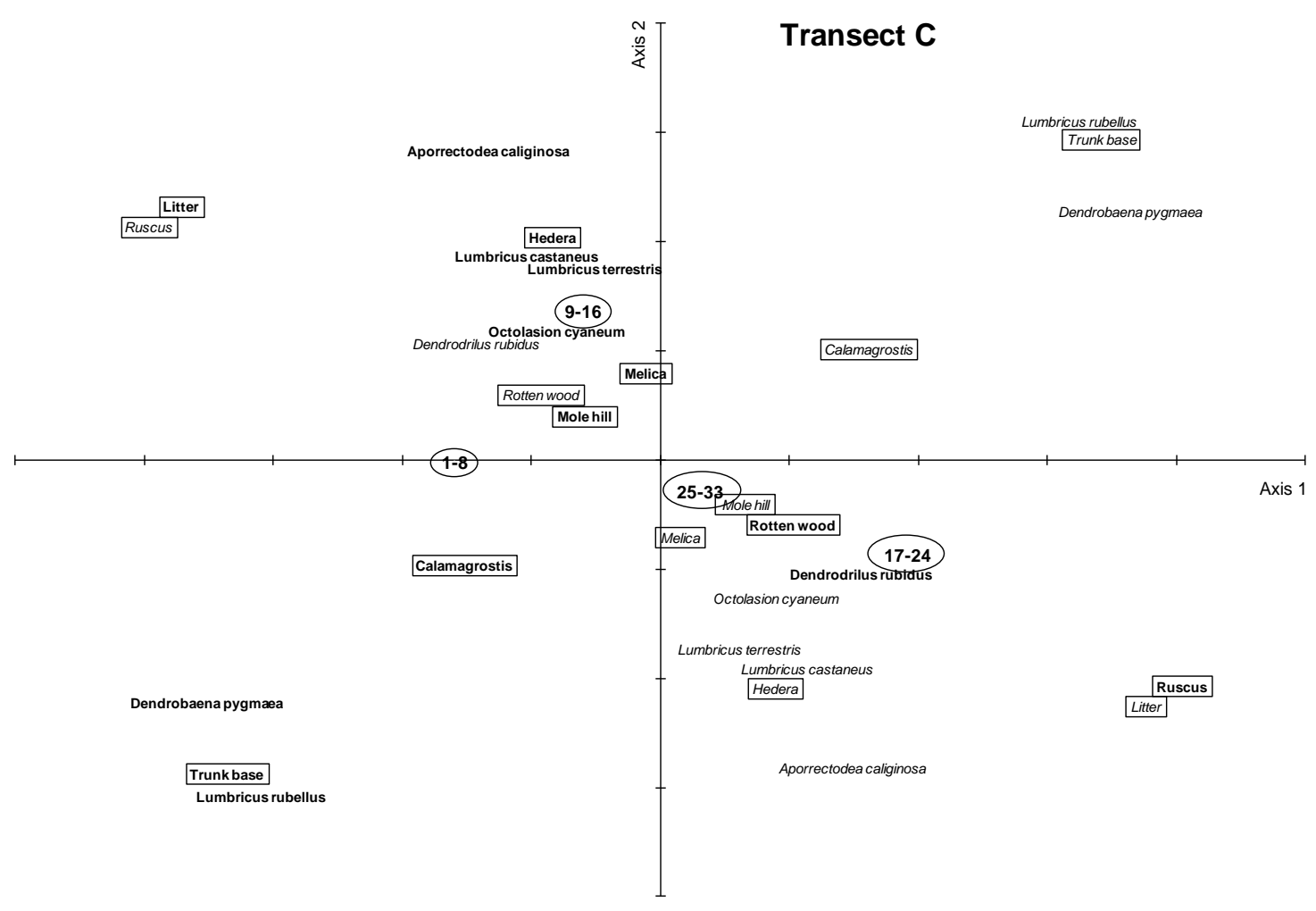

Fig. 7 


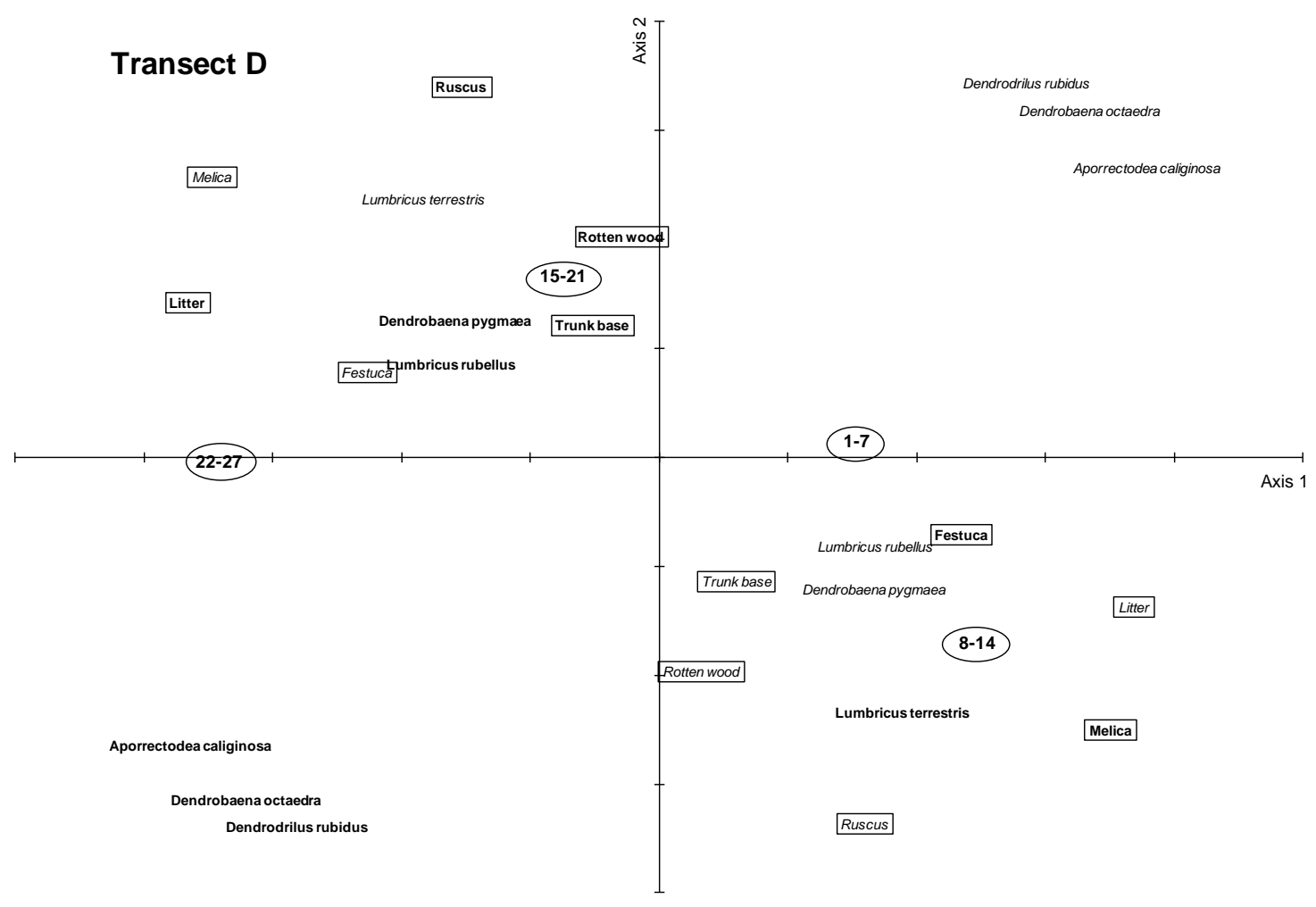

Fig. 8 


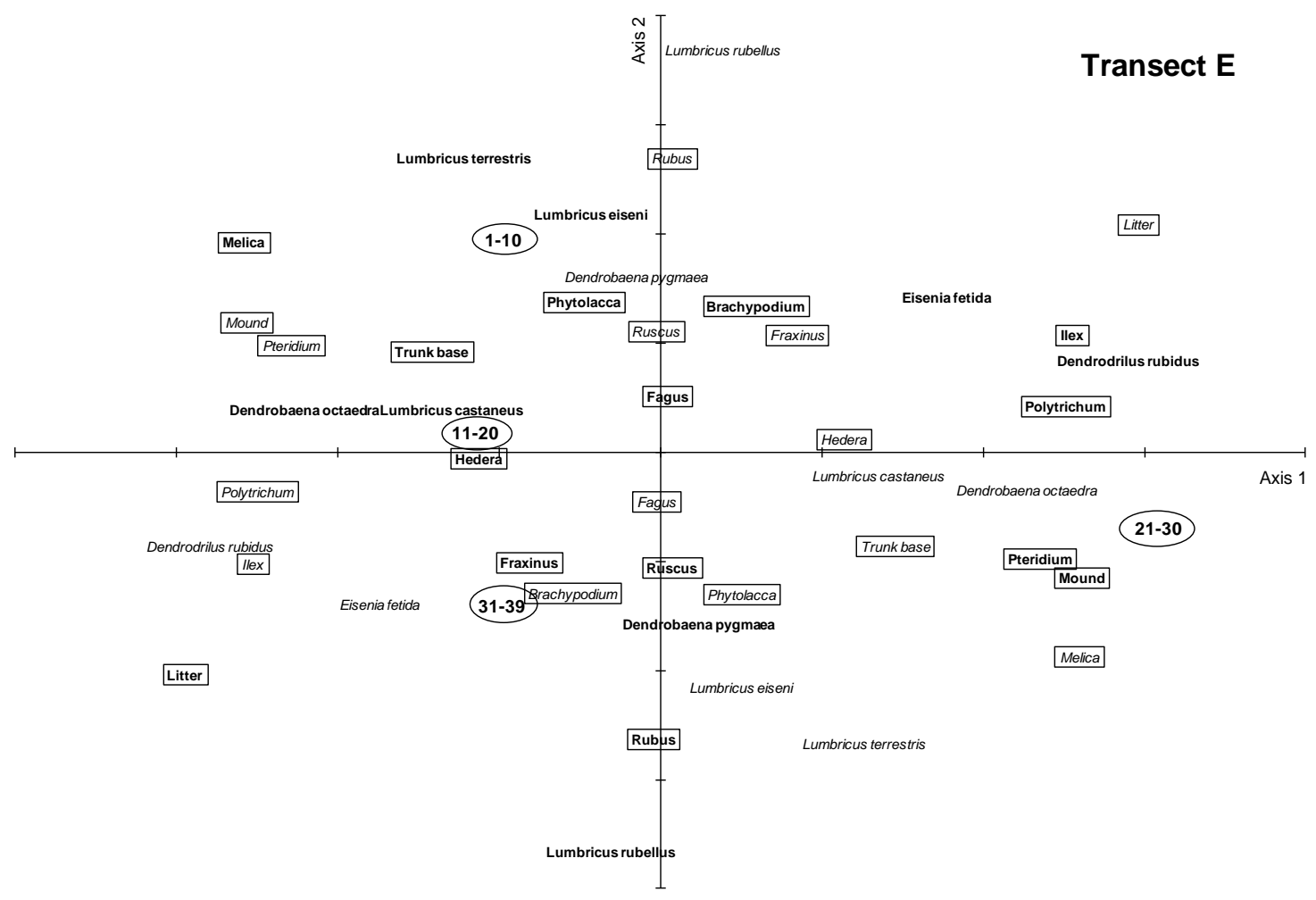

Fig. 9 